\title{
TERT wt Allele
}

National Cancer Institute

\section{Source}

National Cancer Institute. TERT wt Allele. NCI Thesaurus. Code C52497.

Human TERT wild-type allele is located in the vicinity of $5 p 15.33$ and is approximately 42

$\mathrm{kb}$ in length. This allele, which encodes telomerase reverse transcriptase protein, is involved in the replication of telomeres. Aberrant expression of the allele at elevated levels may contribute to oncogenesis. 